Article

\title{
Representative Bureaucracy and the Role of Expertise in Politics
}

\author{
Jarle Trondal ${ }^{1,2, *}$, Zuzana Murdoch ${ }^{1,3}$ and Benny Geys ${ }^{4,5}$ \\ ${ }^{1}$ Department of Political Science, University of Agder, 4604 Kristiansand, Norway; E-Mails: jarle.trondal@uia.no (J.T.), \\ zuzana.murdoch@uia.no (Z.M.); Tel.: +47-3814-1561 (J.T.) \\ ${ }^{2}$ ARENA-Centre for European Studies, University of Oslo, 0318 Oslo, Norway \\ ${ }^{3}$ Organization and Governance Studies, University of Bremen, 28359 Bremen, Germany \\ ${ }^{4}$ Department of Applied Economics, Vrije Universiteit Brussel, 1050 Elsene, Belgium \\ ${ }^{5}$ Norwegian Business School BI, 0484 Oslo, Norway; E-Mail: benny.geys@bi.no \\ * Corresponding author
}

Submitted: 14 May 2014 | In Revised Form: 1 September 2014 | Accepted: 24 September 2014 |

Published: 31 March 2015

\begin{abstract}
The vast majority of existing studies on bureaucratic representation focus on bureaucracies' permanent and internal staff. Yet, the rising sophistication of modern democracies and the technocratization of political life are gradually inducing an increased reliance on external experts to assist in the development and implementation of policy decisions. This trend, we argue, raises the need to extend studies of bureaucratic representation to such external and non-permanent experts in governmental affairs. In this article, we take a first step in this direction using seconded national experts (SNEs) in the European Commission as our empirical laboratory. Our results highlight that Commission SNEs do not appear representative of their constituent population (i.e., the EU-27 population) along a number of socio-demographic dimensions. Moreover, we find that the role perception of "experts" is primarily explained by organizational affiliation, and only secondarily by demographic characteristics (except, of course, education).
\end{abstract}

\section{Keywords}

bureaucracy; European Commission; expertise; representation; seconded national experts

\section{Issue}

This article is part of the special issue "The Role of Expert Knowledge in EU Executive Institutions", edited by Professor Åse Gornitzka (University of Oslo, Norway) and Dr. Cathrine Holst (University of Oslo, Norway).

(C) 2015 by the authors; licensee Cogitatio (Lisbon, Portugal). This article is licensed under a Creative Commons Attribution 4.0 International License (CC BY).

\section{Introduction}

With the rising sophistication of modern democracies, the "business of governance [has become] more difficult" (Flinders, 2014, p. 3). Simultaneously, the "technocratization of political life" (Bickerton, 2012, p. 14) has increased the role of "experts" and their "ways of doing things" in processes of proposing, implementing and legitimizing public policy (Barnett \& Finnemore, 2004; Joerges, 1999; Joerges, Ladeur, \& Vos, 1997, p. 7; Radaelli, 1999; Rayner, 2003, p. 163; Weingart, 1999). This trend towards increased reliance on external experts in the development and implementation of policy deci- sions has thus far failed to receive attention in the vast literature on bureaucratic representation, which has focused exclusively on bureaucracies' permanent and internal staff (Kennedy, 2014; Meier \& Capers, 2013; Rhodes, Hart, \& Noordegraaf, 2007). Yet, understanding the representativeness of external experts is important because such "knowledge agents have intrinsic governance capacities in their power to define problems...or engage in standard-setting, rule-making, or other regulatory activity" (Stone, 2012, p. 329). Hence, their discretionary power may have important consequences for what premises are made available to decision-makers (Pennock, 1968). This study therefore contributes to 
contemporary scholarship on representative bureaucracy (RB) by explicitly turning attention to the representativeness of external and non-permanent experts in governmental affairs.

From a theoretical perspective, we argue that the increased reliance on experts and external expertise in contemporary public policy-making requires a fundamental re-assessment of how the representativeness of the public sector workforce and its policy decisions is evaluated. This assertion rests on the fact that external experts are often recruited on time-limited contracts that only run as long as their specific expertise is required. ${ }^{1}$ Moreover, these contracts are often awarded outside the standard recruitment procedures. The implied recruitment flexibility can generate either an improvement of passive (or descriptive) representation within the bureaucracy (when such contracts are employed to bolster staff contingents that are underrepresented in the permanent staff), or a deterioration of the bureaucracy's representativeness (when experts with unfavourable characteristics tend to be excluded in favour of those with more desirable features). Such potential shifts in passive representativeness may be important because they have the potential to translate into an active (under)representation of possibly relevant interests and opinions (Kennedy, 2013; Schröter \& von Maravić, 2014). ${ }^{2}$

Following the advice of Kennedy (2014, p. 414), this study measures active representation by the representative role perceptions evoked by office holders. More specifically, our focus is directed towards officials' perception as "expert". To the extent that government officials perceive themselves to be an "expert", it is assumed that they would act according to an "epistemic logic" (see below). Officials would thus prepare dossiers, argue and negotiate on the basis of their

1 The current trend towards "agencification" in (inter)national public-sector environments (Trondal, 2014) makes that bureaucrats with very specific expertise often become employed on long-term contracts in very specialised agencies. Although such agencies raise interesting issues of representation and legitimacy in their own right and deserve more in-depth attention in future research, they fall outside the scope of our current analysis. This article deals exclusively with external experts.

${ }^{2}$ Although recent work on RB has often uncovered a link between passive and active representation (Meier, 1993; Atkins \& Wilkins, 2013; Hindera, 1993), it is not required that a bureaucracy is representative in a descriptive sense for it to take decisions that are representative in a substantive sense, or vice versa (Mosher, 1968; Pitkin, 1967). Kennedy (2013), for instance, illustrates that one does not have to be disabled to actively represent the interests of those who are, while O'Connor (2014) suggests that elite level bureaucrats may actively represent professional or technocratic ideas. More recent work illustrates that active representation requires two critical conditions: i) critical mass and ii) issue of importance to the particular minority (for excellent overviews, see Lim, 2006; Meier \& Nicholson-Crotty, 2006). professional competences, and legitimate their authority on scientific aptitudes and capabilities (Haas, 1992; Rayner, 2003; Rutgers \& Mentzel, 1999). As such, their involvement in the policy-making process would tend to come with a "promise [of] objectivity and transparency" (Rayner, 2003, p. 163). Still, as documented in a substantial philosophy of science literature discussing the ever closer connections between expertise and politics (e.g., Rutgers \& Mentzel, 1999; Weingart, 1999), this is not always self-evident in practice. Experts may also contribute to a "mobilization of bias" in public policy-making (Schattschneider, 1975) because they may interpret relevant decision-making premises (data) differently from elected office-holders (Sutcliffe \& Weick, 2008 , p. 62) and thereby systematically induce active under-representation of certain information.

Our empirical analysis concentrates on "external experts" in the European Commission (Commission)the so-called Seconded National Experts (SNEs). These are recruited from member-state administrations into the Commission on temporary contracts (maximum six years), and are specifically recruited to provide expertise to the Commission in areas where this might be lacking in permanent staff. The data derive from Eurostat, official documents detailing the staff composition of the Commission, as well as a unique survey among Commission SNEs ( $N \approx 450$ ). We first of all employ these data to assess whether Commission SNEs reflect the characteristics of their constituent population (the EU-27 population); i.e., passive representation. ${ }^{3}$ This indicates that SNEs are not a close match to the composition of the EU-27 population in terms of gender, education, age and geographical origin. Still, one might wonder whether such passive (mis)representation really matters: i.e., does the demographic background of public officials affect their self-perception of being an "expert"? Our data suggests that it may not. Indeed, the active role perception of experts appears to be primarily explained by their organizational affiliation, and only secondarily by their demographic characteristics. Only the educational background variable-among all demographic variables - has a substantive and significant effect on active "expert" representation.

In the next section, we briefly discuss the growing role of experts and expertise in public policy-making. Building on the foregoing RB literature, this section also indicates how this tendency might affect bureaucratic representativeness. Then, in Section 3, we use a variety of datasets to unveil Commission SNEs' representativeness relative to the EU27-population. Finally, Section 4 concludes and discusses some avenues for further research.

\footnotetext{
3 Following the recent accession of Croatia, the EU meanwhile has 28 members. This had not yet occurred at the time of our data collection, such that we treat the EU-27 population as the EU's relevant constituent population.
} 


\section{Expertise in Politics}

\subsection{A Note on Expertise}

Expertise is much more than the mechanical production of data and analysis. Expert knowledge grants access to constituting basic rules for cause and effect, distinguishing right from wrong, categorising social phenomena and advising about good and bad. As a result, expertise has become an institution in itself, loaded with authority and power. Moreover, expert authority bestows its holder with legitimacy and a communicative platform that reaches far beyond the narrow scientific discipline. It is, however, not any kind of knowledge that functions as the key to authority and power; only "recognised knowledge" matters. Universities have traditionally been the places with a monopoly on such recognised knowledge (Djelic, 2006; Drori \& Meyer, 2006; Drori, Meyer, Ramirez, \& Schofer, 2003; Maasen \& Olsen, 2007; Paradeise, Reale, Bleiklie, \& Ferlie, 2009; Ramirez, 2006; Savigny, 2013; Weingart, 1999). Today, political actors-public and private, national and international-seek to establish expert-based authority founded on the idea of evidence-based rulemaking. Apart from seeking i) rational-legal authority based on the idea of impersonal rulemaking, or ii) delegated authority based on the idea of accountable rulemaking, or iii) moral authority based on the idea of normative or principled rulemaking, the role of knowledge thus seems to have become central in how political actors engage in processes of authoritybuilding and in how they go about legitimizing it (Barnett \& Finnemore, 2004; Maasen \& Olsen, 2007).

Expertise as the basis for authority was central to Max Weber, who considered rationalisation as one of the most important characteristics of the development of western society and capitalism (Wrong, 1970). Yet, almost paradoxically, "the increased use of scientific expertise by policy-makers has not increased the degree of certainty, in fact it becomes de-legitimating" (Weingart, 1999, p. 151). The reason is that the increasing use of expertise inflates the demand for such expertise, which drives the "recruitment of expertise far beyond the realm of consensual knowledge (...) to the research frontier where knowledge claims are uncertain, contested and open to challenge" (Weingart, 1999, p. 158). It might also push towards a "politicisation" of expertise, where the objectivity of the expert scientist is brought in doubt due to his/her involvement in public policy controversies (Brooks, 1975).

Nevertheless, purely epistemic communities, to the extent that they exist (Haas, 1992), in principle do not work under the shadow of politicians; they work under the shadow of the rules of the expert community. Members of an expert community are each other's judges-accountability is turned inwards (Haas, 1990, 1992). Public officials - such as Commission SNEs - who evoke an expert role are expected to enjoy behavioural discretion, and are influenced by external professional reference groups (Wilson, 1989). They are assumed to prepare dossiers, argue and negotiate on the basis of their professional competences and to legitimate their authority on scientific competences (Haas, 1992). Their behaviour is expected to be guided by considerations of scientific and professional correctness and the power of the better argument (Eriksen \& Fossum, 2000). Their role perceptions and loyalties are primarily directed towards their expertise and educational background as well as towards external professional networks. This is the "expert official" who perceives her-self to be an institutionally independent technocrat. She is driven by a so-called "technical self-determination" (Pentland, 1973, p. 74). Moreover, bureaucratic organizations infused with an epistemic logic are a challenge to institutional unity. Such institutions are characterized by being composed of loosely coupled experts with an "out-ward" orientation. Such organizations are typically porous and open, staffed by actors from different external expert institutions such as domestic agencies, universities, research institutions etc. (Olsen, 2007; Trondal, 2013).

\subsection{Experts and Representative Bureaucracy}

The theory of RB assumes that the diversity and representativeness of the public sector workforce impacts on how public sector organizations perform, how they are internally controlled, how legitimate they are perceived to be, and how they relate to their constituent populations (Andrews,Boyne, Meier, O'Toole, Walker, 2005; Selden, 1997; Schröter \& von Maravić, 2014; Stevens, 2009). This reflects the key notion that what civil servants bring with them into the organization is of significance to their conduct (Hooghe, 2005, 2012).

From a normative viewpoint, this implies that "representation and staffing carries important implications for the delivery of public services [and] the sharing of power in society" (Schröter \& von Maravić, 2014, p. 6). That is, a more RB takes into account a wider variety of ideas and opinions in the society at large. RB has been linked to improved overall administrative performance (e.g., Kingsley, 2003), increased worker loyalty and job satisfaction (e.g., Choi, 2009) and higher legitimacy and accountability of the bureaucratic organization (e.g., Selden \& Selden, 2001). RB has also been seen to play a symbolic role during the implementation of controversial or unpopular policy programs (Peters, Schröter, \& von Maravić, 2013; Pitts, Hicklin, Dawes, \& Melton, 2010) and with regards to opportunities and equity to public office (Gravier, 2013; Groeneveld \& van de Walle, 2010; Peters et al., 2013).

From a RB perspective, the increasing reliance on external expertise in public policy-making (see above) raises important questions about experts' representa- 
tiveness. The reason is that such experts are generally appointed to provide a specific type of information or knowledge. This is particularly so among experts who have temporal appointments and who are recruited largely outside the standard recruitment procedures for permanent staff. Clearly, such recruitment flexibility may be employed-whether consciously or subconsciously-to bolster staff contingents that are underrepresented in the permanent staff (or moderate staff contingents that are over-represented). If so, this may affect passive (or descriptive) representation within the bureaucracy. Nonetheless, when experts with (perceived) unfavourable characteristics-or policy opinions-become excluded, such recruitment flexibility may also induce a deterioration of the bureaucracy's representativeness. The latter is not an unrealistic scenario. Several observers indeed argue that it has "become commonplace that the adversarial parties (...) engage scientific experts to present evidence which supports their respective views" (Weingart, 1999, p. 156; see also Brooks, 1975).

The above discussion naturally raises the second question whether individuals with higher expertise levels are also more likely to perceive themselves as "independent experts" and act in accordance with the prescripts of such a role? According to the idea of individual pre-socialization outside organizations, officials may be "pre-packed" already before entering the organization (Pfeffer, 1982, p. 277; Selden, 1997). Individual pre-socialization outside organizations is important to account for, because most studies of elite socialization do not systematically control for the effect of pre-socialization and self-selection (Beyers, 2005, 2010; Hooghe, 2005). This article uses the following demographic factors as proxies of individual presocialization: age (in years), gender, educational background (fields of study, place of study, and level of graduation), and country of origin. Finally, seniority is applied as a control variable, such as to account for the idea that organizational re-socialization inside an organization may modify the effect of individual presocialization outside the organization.

First, on gender, studies suggest that female officials in the Commission have a somewhat different belief structure than male officials-for example with respect to their stronger general "supranational orientation" (Kassim et al., 2013, p. 111; Trondal, Murdoch, \& Geys, 2014). Our question is whether the gender of experts leads to different emphasis on their expert role. Next, previous studies show no age effect as regards Commission officials' general beliefs (Kassim et al., 2013). Thus, the age variable is applied in this study without any predefined prediction. Third, the educational background of office holders has shown a significant effect in previous studies. A first education-related prediction is that length of education might matter-measured by the highest attained degree. We expect that individuals with a doctorate have (much) stronger perceptions of being an expert compared to those without a doctorate. Secondly, it may be expected that different fields of study vary in their influence on the strength of one's self-perceptions of being an expert. Conceptualised as a continuum, "hard" and "soft" disciplines are indeed often characterised by degrees of paradigmatic status and consensus (Becher, 1989; Braxton \& Hargens, 1996; Smeby, 2000). Thus, officials with an educational background in "hard" sciences-such as physics, biology-may see themselves more strongly as experts than officials educated in relatively "soft" sciences-such as social sciences. Finally, we might expect that place of study matters. One might indeed hypothesize that having an international educational background may be conducive to evoking an expert role. The reason is that one's education then is not tied to one particular environment, but rather was obtained in a more diffuse array of settings. This, in turn, may induce a focus on the content-or expertise-of the study.

Finally, country of origin measures experts' national pre-socialization. One might expect that experts originating from new and "un-socialized" member states give more priority to national concerns whereas the expert role has been more internalized among their colleagues from earlier accession countries. Experts originating from the old EU member states might thus be expected to have learned the "expert game" better than their colleagues from the new(er) member states, who are likely to be less pre-socialised into a "European state of mind" (dominant in the Commission's DGs; Ban, 2013).

\section{Empirical Analysis}

\subsection{Case Selection and Datasets}

Our empirical analysis of passive and active "expert" representation of Commission SNEs relies on a number of different data sources. First, to measure passive representation we collected information about the characteristics of the European population, since this is the most relevant comparison group to evaluate the representativeness of European-level bureaucrats (Gravier, 2008, 2013; Stevens, 2009). Information about the socio-demographic characteristics (i.e., gender, age, educational background and nationality) of the population in the EU27 was obtained from Eurostat. Second, we collected information about the staff composition of the Commission. This is obtained from official publications of the Commission including, but not restricted to, the 2011 European Commission Human Resource Report, the Draft General Budget 2012 and online publications documenting the Distribution of Staff by Statutory Links and DGs. (European Commission, 2011a, 2011b, 2011c). ${ }^{4}$

${ }^{4}$ The year of analysis-2011-is determined by the year in 
Secondly, to measure active "expert" representation we conducted a unique web-based survey administered between January and April 2011 to all 1098 then active SNEs in the Commission. This survey received 667 responses, which equals a response rate of just over 60 percent. As not all SNEs answered all questions relevant to the present analysis, the final sample employed in the analysis hovers around 400 to 450 respondents. It is important to note that the distribution of the SNEs in our final survey sample across Directorate-Generals (DGs) compares to that observed for all Commission SNEs in 2011. This similarity suggests that non-response within the targeted population was independent of the DG in which SNEs work, which improves the generalizability of the results reported below.

\subsection{Passive Representation}

Table 1 presents the composition in terms of gender, education, age and geographical origin of the European population (EU27), the Commission's total staff, and Commission's SNEs. While the first three sociodemographic characteristics are commonly included in RB studies (Kennedy, 2014), the last characteristic (i.e., geographical origin) arguably becomes a more important dimension of representation for international bureaucrats (Egeberg, 2006; Gravier, 2008, 2013; Trondal, Suvarierol, \& van den Berg, 2008). Table 1 documents geographical origin of officials by wave of enlargement (which reflects a country's EU membership seniority): countries in the original EU6 (Belgium, the Netherlands, Luxembourg, Italy, France and Germany) vs. EU15 (EU6 plus Sweden, Finland, Denmark, Spain, Portugal, Austria, Ireland, United Kingdom and Greece).

Looking first at standard demographic characteristics generally included in RB studies, Table 1 indicates that the gender composition of the total Commission workforce ( $52 \%$ female) very closely resembles that of the overall European population (52\% female). Women are, however, substantially under-represented among SNEs ( $40 \%$ female). The same is also true among the Commission' permanent AD-level staff (40\% female), which automatically implies that they are strongly over-represented in Assistant (AST) level positions that deal with assistant and secretarial tasks (65\% female; not reported in Table 1). This gender division creates a significant potential for under-representation of female viewpoints in the Commission's policy work and expert input. The age distribution of the Commission's permanent staff witnesses an under-representation at both extremes of the age distribution, and is clustered strongly in the 40-60 age range (who is strongly overrepresented compared to the EU27-population). The age distribution among SNEs to some extent corrects

which our survey among the Commission's SNEs took place (see below). for both deviations. Yet, this correction is imperfect as SNEs themselves at best approach the age distribution of the EU27-population.

With respect to educational background, we naturally observe a very strong over-representation among SNEs for variables reflecting specific forms of expertise (i.e., having studied outside one's home country, or holding a doctorate). Just over $19 \%$ of all SNEs have completed at least part of their education outside their home country, and no less than $20 \%$ obtained a doctorate. The equivalent numbers in the EU27 population are $3 \%$ and $1 \%$, respectively. ${ }^{5}$ Moreover, while social scientists (including economists and political scientists) are slightly over-represented relative to the share of tertiary graduates with such a degree in the European population, lawyers are over-represented within the Commission's expert staff (16\% versus $5 \%$ in the EU27). The latter may reflect that legal expertise is highly valued for drafting official documents and delimiting discussions within the boundaries of EU law.

Finally, compared to the share of the EU27population living in EU6 (47\%) and EU15 (80\%) countries, Commission's permanent AD-level staff appears to face a slight over-representation of employees from the six "oldest" member states. The reverse conclusion holds among SNEs employed in the Commission, since the old(er) Member States are strongly underrepresented in this group. The latter suggests that the Commission is using such temporary positions to incor-

Table 1. Representation by gender, education, age and geographical origin (per cent).

\begin{tabular}{llll}
\hline & EU27 & All staff & SNEs \\
\hline Women & 52 & 52 & 40 \\
Social Science & $28^{\mathrm{a}}$ & na & 37 \\
Law & $5^{\mathrm{a}}$ & na & 16 \\
Study Abroad & $3^{\mathrm{b}}$ & na & 19 \\
PhD & $1^{\mathrm{c}}$ & na & 20 \\
19-40 years & 44 & 32 & 41 \\
40-50 years & 23 & 37 & 30 \\
50-60 years & 21 & 27 & 18 \\
60-65 years & 11 & 4 & 11 \\
EU6 & 47 & 51 & 30 \\
EU15 & 80 & 80 & 62
\end{tabular}

Notes: ${ }^{2}$ Share of tertiary graduates with a degree in a particular field of education; ' ${ }^{\text {}}$ Students studying in other EU27, EEA or candidate country, as percentage of total student population; ' Estimate based on tertiary education graduates as percent of population in EU27 (23.7\% in 2011) and the share of tertiary graduates finishing a doctorate $12.6 \%$ in 2004); na is 'not available'. Sources: Eurostat; OECD; European Commission (2011a, 2011b, 2011c); Authors' survey among Commission SNEs.

\footnotetext{
${ }^{5}$ Note that the EU27 figures exclude individuals studying in, for instance, the United States, Canada or Asian countries. Nevertheless, since intra-EU study-related travel is more common than extra-EU travel, this is unlikely to have a significant influence on our results.
} 
porate officials from countries that acceded to the EU in, or after, the 2004 accession round (see also Ban, 2013).

Table 1 only looks at the Commission as a whole. Yet, the results thus obtained need not play out similarly across all different sections of this large and diverse bureaucracy (Kennedy, 2012; Meier \& Capers, 2013; Schröter \& von Maravić, 2014). Research in organisation theory indeed indicates that decision-making logics vary substantially across policy areas (Egeberg, 2012a). Within the EU, for instance, it is easy to imagine that bureaucrats have less leeway for personal initiative in sensitive policy areas (such as agriculture, regional policy, or development aid) compared to less sensitive areas (such as research and innovation or mobility and transport). Different policy areas represented in the Commission may also foster different cultures of representation (Kennedy, 2014), which can become reflected in the (interpretation of) staffing policies (Cayer \& Sigelman, 1980; Gravier, 2013; Murdoch \& Geys, 2014). Consequently, and following recent suggestions to "bring institutional variety back into diversity research" (Schröter \& von Maravić, 2014, p. 4), Table 2 depicts the representativeness of SNEs across seven sets of DGs covering distinct policy areas (previously differentiated by Murdoch and Trondal (2013)). ${ }^{6}$

As expected, the representation of different population groups varies across policy areas. This holds first of all in terms of educational background: that is, we observe substantial over-representation of social scientists in DGs occupied with External Relations and Research, while lawyers cluster in Central DGs. SNEs with a doctorate are, unsurprisingly, strongly represented in Research DGs. The same can also be observed with respect to SNEs' age distribution (i.e., younger SNEs are over-represented in Market and Provision DGs, and older SNEs in Supply and Provision DGs) and gender (i.e., while female SNEs face stronger under-representation in Market-, Supply-, and Research-related DGs, they are representative of the EU27-population in DGs linked to the Commission administration ("Central")). Although the latter could in part reflect that these DGs provide more "female" occupations (as also observed via the higher share of women in "female" Assistant positions), ${ }^{7}$ it could also suggest that the administrative

\footnotetext{
${ }^{6}$ We lack similarly differentiated data about Commission's permanent staff, such that the analysis here necessarily relies on our sample of SNEs. The seven policy areas are "Market", which is comprised of DGs COMP, ECFIN, ENTR and MARKT; "External Relations" is DGs ELARG, DEVCO, FPI, ECHO and TRADE; "Social Regulation" is DGs CLIMA, EAC, EMPL, ENV, SANCO, HOME and JUST; "Supply" is DGs ENER, CNECT, MOVE, RTD and TAXUD; "Provision" is DGs AGRI, MARE and REGIO; "Research" is DGs ESTAT and JRC; Central consists of BUDG, COMM, IAS, BEPA, SJ and OLAF (DG acronyms are explained in the appendix).

7 Job typology may indeed give rise to "gendered" expectations concerning the performance, ability or "fit" of job can-
}

DGs in the Commission may have a stricter enforcement of gender-equality standards. These DGs may be more directly involved in setting up and maintaining administrative procedures such as non-discriminatory hiring arrangements.

\subsection{Active Expert Representation: Does Background Matter?}

In this section, we turn to examining Commission SNEs' role perception as an "expert". The key question here is whether SNEs with higher expertise levels are also more likely to perceive themselves as independent experts in their day-to-day decision-making, and act in accordance with the prescripts of such an epistemic role. This is often expected from "administrators who perceive their role as that of an advocate or representative of minority interests" (Selden, 1997, p. 140), but has not been directly tested for experts. It is important to observe here that we operationalize active "expert" representation by SNEs' role perceptions (i.e., the extent to which they feel they perceive themselves as independent experts in their daily work) rather than actual policy decisions or outcomes. The reason behind this operationalization is that the discretionary power of bureaucrats is critical for active representation (Meier, 1993; Sowa \& Selden, 2003). Final outputs, however, unlike personal decisions and individuals' perceptions thereof, are often determined by numerous factors beyond bureaucratic control (such as, for instance, citizen coproduction of public goods and services; Whitaker, 1980; De Witte \& Geys, 2011, 2013), which limits their relevance in measuring active representation (Bradbury \& Kellough, 2007). We thus study "the potential for active representation (...) rather than seeking evidence of policy outcomes in line with the interests of specific groups" (Bradbury \& Kellough, 2007, p. 698). The analysis relies on the following simple regression model (with subscript i referring to SNEs):

ExpertRole $_{i}=\alpha+\beta_{1}$ Gender $_{i}+\beta_{2}$ Age $_{i}+\beta_{3}$ EduType $_{i}+$ $\beta_{4}$ StudyAbroad $_{i}+\beta_{5}$ PhD $_{i}+\beta_{6}$ EU6 $_{i}+\beta_{7}$ EU15 $_{i}+\beta_{8}$ SNEyear $i+\varepsilon_{i}$

Where "ExpertRole" is based on the question: "In your daily work, to what extent do you feel you act as an independent expert?". It is coded using a six-point scale from "fully" (coded as 0) to "not at all" (coded as 5), which requires estimating an ordered logit model. We also cluster standard errors by either DG or country of

didates for specific jobs. This may lead recruiters to have a preference for women over men (and vice versa) for certain types of jobs (Heilman, 1995; Watts, 2009), but may also affect applicants since gender stereotypes are known to have important self-fulfilling effects (Harris \& Rosenthal, 1985; Miller \& Turnbull, 1986). 
origin to account for the fact that answers from SNEs within one DG (or from the same home country) may not be fully independent from one another.

The key explanatory variables are SNEs' age (in years), gender ( 1 if male), educational background ("EduType"; separate indicator variables for a degree in economics, political science or law), whether or not the SNE studied abroad ( 1 if yes) or obtained a doctorate (1 if yes), and SNEs' country of origin (separate indicator variables for EU6 and EU15). We also include the number of years (s)he has been working in the Commission, as exclusion of this variable may have a confounding effect of our estimate of the effect of SNEs' age. SNEs' seniority in the Commission is thus applied as a control variable, suggesting that organizational re-socialization inside the Commission to some extent may modify the effect of individual pre-socialization outside the Commission. The results are summarized in Table 3.

Table 3 suggests that only the educational background variable has a significant effect on SNEs' active representation as "experts". First, we see that SNEs with a doctorate are much more likely to invoke their role as an independent expert. Thus, the length of presocialization inside university organizations makes officials more expert-oriented. Secondly, SNEs with degrees in social sciences-such as economics and political science-are significantly less likely to state that they act as an independent expert in their daily work in the Commission (compared to law and "other" degrees). This suggests that social science degrees lead to lower expert orientations, which might reflect the relative absence of uncontested scientific "laws" in such disciplines (as compared to law or "hard" sciences such as physics and engineering). Other demographic variables such as age, place of education and country of origin have no explanatory power. Finally, and supporting previous research, organizational re-socialization inside organizations affects the role perceptions of office holders (e.g., Egeberg, Gornitzka, \& Trondal, 2015) since we see that SNEs' self-perception as "expert" tends to strengthen with the number of years in the Commission. Though not reported above, these results are robust to the inclusion of direct controls for working in specific DGs, which implies that individuals' characteristics are driving the above results rather than the DGs SNEs work in within the Commission (see above).

\section{Conclusion}

Not surprisingly, in terms of a number of basic sociodemographic background characteristics, Commission SNEs can barely be called passively representative of the overall EU27-population. SNEs are significantly more likely to be male officials with a degree in law from the "new" member states that acceded in or after the 2004 accession round. The only exception is experts' age, since the age distribution among Commission's SNEs appears a substantially closer match to that of the EU27 population than the age distribution among Commission's permanent AD-level staff. More importantly, however, this study suggests that only the educational background variable-among all demographic variables-has a significant effect on active expert representation. Organizational re-socialization inside organizations appears a stronger signifier of role perceptions-such as the expert role-among office holders (e.g., Egeberg, Gornitzka, \& Trondal, 2014), since we see that SNEs' self-perception as an independent expert tends to strengthen with the number of years in the Commission.

Table 2. Representativeness of Commission SNEs by policy area ( $\mathrm{N} \approx 452)$ (per cent).

\begin{tabular}{lllllllll}
\hline & EU27 & $\begin{array}{l}\text { Market }(\mathrm{N} \\
=71)\end{array}$ & $\begin{array}{l}\text { External } \\
\text { Relations } \\
(\mathrm{N}=65)\end{array}$ & $\begin{array}{l}\text { Social } \\
\text { Regulation } \\
(\mathrm{N}=123)\end{array}$ & $\begin{array}{l}\text { Supply }(\mathrm{N}) \\
=87)\end{array}$ & $\begin{array}{l}\text { Provision } \\
(\mathrm{N}=25)\end{array}$ & $\begin{array}{l}\text { Research } \\
(\mathrm{N}=54)\end{array}$ & $\begin{array}{l}\text { Central (N } \\
=20)\end{array}$ \\
\hline Women & $\mathbf{5 2}$ & 38 & 46 & 46 & 34 & 39 & 31 & 50 \\
Social Science & $\mathbf{2 8}$ a & 48 & 51 & 30 & 26 & 32 & 50 & 35 \\
Law & $\mathbf{5}^{\text {a }}$ & 20 & 11 & 21 & 16 & 4 & 0 & 35 \\
Study Abroad & $\mathbf{3}^{\mathbf{b}}$ & 20 & 23 & 19 & 14 & 28 & 15 & 25 \\
PhD & $\mathbf{1}$ & 18 & 17 & 24 & 18 & 8 & 31 & 10 \\
19-40 years & $\mathbf{4 4}$ & 56 & 35 & 40 & 33 & 52 & 35 & 45 \\
40-50 years & $\mathbf{2 3}$ & 30 & 32 & 29 & 31 & 12 & 33 & 40 \\
50-60 years & $\mathbf{2 1}$ & 7 & 22 & 20 & 21 & 20 & 20 & 10 \\
60-65 years & $\mathbf{1 1}$ & 7 & 11 & 11 & 15 & 16 & 11 & 5 \\
EU6 & $\mathbf{4 7}$ & 38 & 28 & 25 & 32 & 16 & 33 & 40 \\
EU15 & $\mathbf{8 5}$ & 72 & 71 & 61 & 63 & 48 & 54 & 70 \\
\hline
\end{tabular}

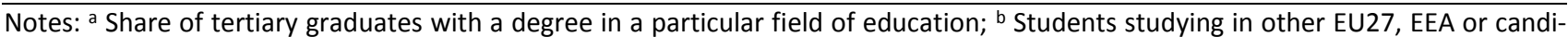
date country, as percentage of total student population; ' Estimate based on tertiary education graduates as percent of population in EU27 (23.7\% in 2011) and the share of tertiary graduates finishing a doctorate (2.6\% in 2004); 'Market' is DGs COMP, ECFIN, ENTR and MARKT; 'External Relations' is DGs ELARG, DEVCO, FPI, ECHO and TRADE; 'Social Regulation' is DGs CLIMA, EAC, EMPL, ENV, SANCO, HOME and JUST; 'Supply' is DGs ENER, CNECT, MOVE, RTD and TAXUD; 'Provision' is DGs AGRI, MARE and REGIO; 'Research' is DGs ESTAT and JRC; 'Central' consists of BUDG, COMM, IAS, BEPA, SJ and OLAF; Translation and administrative services are excluded. Source: Authors' survey among Commission SNES 
Table 3. Estimation results.

\begin{tabular}{lll} 
& $\begin{array}{l}\text { ExpertRole (cluster } \\
\text { by DG) }\end{array}$ & $\begin{array}{l}\text { ExpertRole (clu- } \\
\text { ster by country) }\end{array}$ \\
\hline Male (dummy) & $-0.289^{*}(-1.83)$ & $-0.281(-1.61)$ \\
Age (years) & $0.004(0.43)$ & $0.004(0.53)$ \\
PhD & $-0.628^{* *}$ & $-0.641^{* * *}$ \\
& $(-2.48)$ & $(-3.50)$ \\
StudyAbroad & $0.201(0.96)$ & $0.227(0.97)$ \\
Economist & $0.530 * *$ & $0.512 * *$ \\
(dummy) & $(2.44)$ & $(2.38)$ \\
Political Science & 0.490 & $0.475 *$ \\
(dummy) & $(1.46)$ & $(1.89)$ \\
Lawyer (dum- & 0.173 & 0.158 \\
my) & $(0.60)$ & $(0.72)$ \\
EU6 (dummy) & $-0.002(-0.01)$ & $-0.017(-0.07)$ \\
EU15 (dummy) & $-0.015(-0.06)$ & $-0.018(-0.06)$ \\
SNE-year 2 & 0.275 & 0.280 \\
(dummy) & $(0.80)$ & $(0.91)$ \\
SNE-year 3 & -0.041 & -0.036 \\
(dummy) & $(-0.14)$ & $(-0.14)$ \\
SNE-year 4 & -0.232 & -0.209 \\
(dummy) & $(-0.80)$ & $(-0.64)$ \\
SNE-year 5 & $-0.528 *$ & $-0.526 *$ \\
(dummy) & $(-1.89)$ & $(-1.93)$ \\
Wald chi ${ }^{2}$ & $48.25 * * *$ & $68.78 * *$ \\
N & 408 & 409 \\
\hline
\end{tabular}

Note: $t$ statistics based on standard errors corrected for clustering at DG- or country-level between brackets, ${ }^{* * *}$ significant at $1 \%, * *$ at $5 \%$ and $*$ at $10 \%$. The dependent variable uses the question: "In your daily work, to what extent do you feel you act as an independent expert?", coded using a six-point scale from "fully" (coded as 0 ) to "not at all' (coded as 5).

The passive-active representation dichotomy remains under-studied and contested, and deserves more in-depth analyses in future research. Future research on RB should study in greater detail the conditions under which passive representation translates into (a potential for) active representation. Based on our findings, and in line with recent work on the European Parliament (Egeberg et al., 2014), pre-socialization outside organizations might be expected to matter less than organizational re-socialization inside organizations and organizational affiliation. That is, a study of European Parliament officials suggests that individual processes of pre-socialization outside the EP reveal nonsignificance. What matters is whether officials are employed by the EP secretariat or by the political groups ("organizational affiliation") and their length of service in EU institutions ("organizational socialization") (Egeberg et al., 2014). Also, a review of the literature on the role of nationality in Commission decision-making concludes that Commission officials' national background plays only a minor role. However, nationality matters somewhat more regarding commissioners' behaviour, but makes up only one of several components of their highly compound role (Egeberg, 2012b).

In particular, future research on active representation may consider how demographic variables matter under certain conditions: i.e., whether the organiza- tional structure of a group is loose and supplies few relevant premises for behaviour; whether the actor participates in a fairly stable group with clearly stated goals; whether this group is perceived as important; whether membership is durable; whether the group and the values and identities it represents is generally accepted in society; whether there is a clear connection between what the group does and the life of the group members, and whether group belonging is conceived and an important reason for recruitment to the group (Lægreid \& Olsen, 1978, pp. 28-29). Future research should thus examine whether expertise might affect decision-making behaviour (active expert representation) under such conditions.

\section{Acknowledgements}

We are grateful to CLENAD (especially its former president Matthew Snoding) and Nina Bonge (WZB Berlin) for invaluable assistance with the survey, to FWO Vlaanderen for financial assistance (grant nr. G.0022.12 to Benny Geys), and to the Norwegian Research Council ("EURODIV: Integration and division: Towards a segmented Europe?"). The usual caveat applies.

\section{Conflict of Interests}

The authors declare no conflict of interests.

\section{References}

Andrews, R., Boyne, G. A., Meier, K., O’Toole, L., \& Walker, R. (2005). Representative bureaucracy, organizational strategy and public sector performance: An empirical analysis of English local government. Journal of Public Administration Research and Theory, 15, 489-504.

Atkins, D. N., \& Wilkins, V. M. (2013). Going beyond reading, writing and arithmetic: The effects of teacher representation on teen pregnancy rates. Journal of Public Administration Research and Theory, 23, 771-790.

Ban, C. (2013). Management and Culture in an Enlarged European Commission: From Diversity to Unity? Basingstoke: Palgrave Macmillan.

Barnett, M., \& Finnemore, M. (2004). Rules for the World. International Organizations in Global Politics. Ithaca: Cornell University Press.

Becher, T. (1989). Academic Tribes and Territories. Milton Keynes, UK: Society for Research into Higher Education \& Open University Press.

Beyers, J. (2005). Multiple embeddedness and socialization in Europe: The case of Council Officials. International Organization, 59, 899-936.

Beyers, J. (2010). Conceptual and methodological challenges in the study of European socialization. Journal of European Public Policy, 17(6), 909-920. 
Bickerton, C. J. (2012). European Integration. Oxford: Oxford University Press.

Bradbury, M. D., \& Kellough, J. E. (2007). Representative bureaucracy: Exploring the potential for active representation in local government. Journal of Public Administration Research and Theory, 18, 697-714.

Braxton, J. M., \& Hargens, L. L. (1996). Variation among Academic Disciplines: Analytical Frameworks and Research. In J. C. Smart (Ed.), Higher Education: Handbook of Theory and Research (Vol. XI). New York: Agathon Press.

Brooks, H. (1975). Expertise and politics-Problems and tensions. Proceedings of the American Philosophical Society, 119(4), 257-261.

Cayer, N. J., \& Sigelman, L. (1980). Minorities and women in state and local government: 1973-1975. Public Administration Review, 40, 443-450.

Choi, S. (2009). Diversity in the US Federal government: Diversity management and employee turnover in Federal agencies. Journal of Public Administration Research and Theory, 19(3), 603-630.

De Witte, K., \& Geys, B. (2011). Evaluating efficient public good provision: Theory and evidence from a generalised conditional efficiency model for public libraries. Journal of Urban Economics, 69(3), 319-327.

De Witte, K., \& Geys, B. (2013). Citizen coproduction and efficient public good provision: Theory and evidence from local public libraries. European Journal of Operational Research, 224(3), 592-602.

Djelic, M.-L. (2006). Marketization, from Intellectual Agenda to Global Policy-Making. In M.-L. Djelic \& K. Sahlin-Andersson (Eds.), Transnational Governance. Institutional Dynamics of Regulation. Cambridge: Cambridge University Press.

Drori, G. S., \& Meyer, J. W. (2006). Scientization: Making a World Safe for Organizing. In M.-L. Djelic \& K. Sahlin-Andersson (Eds.), Transnational Governance. Institutional Dynamics of Regulation. Cambridge: Cambridge University Press.

Drori, G. S., Meyer, J. W., Ramirez, F. O., \& Schofer, E. (2003). Science in the Modern World Polity. Institutionalization and Globalization. Stanford: Stanford University Press.

Egeberg, M. (2006). Multilevel Union Administration. The Transformation of Executive Politics in Europe. London: Palgrave.

Egeberg, M. (2012a). How Bureaucratic Structures Matter: An Organizational Perspective. In B. G. Peters \& J. Pierre (Eds.), Handbook of Public Administration (2nd ed.). London: Sage.

Egeberg, M. (2012b). Experiments in Supranational Institution-Building: The European Commission as a laboratory. Journal of European Public Policy, 19(6), 939-950.

Egeberg, M., Gornitzka, Å., \& Trondal, J. (2014). People who run the European Parliament. Journal of European Integration. doi: 10.1080/07036337.2014.
935362.

Egeberg, M., Gornitzka, Å., \& Trondal, J. (2015). An Organizational Approach to Governance. In C. Ansell \& J. Torfing (Eds.), Handbook on Theories of Governance. Cheltenham: Edward Elgar.

Eriksen, E. O., \& Fossum, J. E. (Eds.) (2000). Democracy in the European Union. Integration through Deliberation? London: Routledge.

European Commission. (2011a). European Commission Human Resource Report 2011. Brussels: European Commission

European Commission. (2011b). Distribution of staff by statutory links and DGs (situation on 01/05/2011). Retrieved from http://ec.europa.eu/civil_service/ about/figures

European Commission. (2011c). Draft General Budget 2012, Section 3 European Commission, Appropriations Payments for 2011. Brussels: European Commission.

Flinders, M. (2014). Explaining democratic disaffection: Closing the expectations gap. Governance, 27(1), 1-8.

Gravier, M. (2008). The 2004 enlargement staff policy of the European Commission: The case for representative bureaucracy. Journal of Common Market Studies, 46(5), 1025-1047.

Gravier, M. (2013). Challenging the enhancing of the EU's legitimacy? The evolution of representative bureaucracy in the Commission's staff policies. Journal of Public Administration Research and Theory, 23(4), 817-838.

Groeneveld, S., \& van de Walle, S. (2010). A contingency approach to representative bureaucracy. International Review of Administrative Sciences, 76(2), 239-258.

Haas, E. (1990). When Knowledge Is Power. Three Models of Change in International Organizations. Berkeley: University of California Press.

Haas, P. (1992). Epistemic communities and international policy coordination. International Organization, 46(1), 1-35.

Harris, M., \& Rosenthal, R. (1985). Mediation of interpersonal expectancy effects: 31 meta-analyses. Psychological Bulletin, 97, 363-386.

Heilman, M. E. (1995). Sex stereotypes and their effects in the workplace: What we know and what we don't know. Journal of Social Behavior and Personality, 10, 3-26.

Hindera, J. J. (1993). Representative bureaucracy: Further evidence of active representation in the EEOC district offices. Journal of Public Administration Research and Theory, 3, 415-429.

Hooghe, L. (2005). Several roads lead to international norms, but few via international socialization. A case study of the European Commission. International Organization, 59, 861-898.

Hooghe, L. (2012). Images of Europe: How Commission officials conceive their institution's role. Journal of 
Common Market Studies, 50(1), 87-111.

Joerges, C. (1999). Bureaucratic Nightmare, Technocratic Regime and the Dream of Good Transnational Governance. In C. Joerges \& E. Vos (Eds.), EU Committees: Social Regulation, Law and Politics. Oxford: Hart Publishing.

Joerges, C., Ladeur, K.H., \& Vos, E. (Eds.) (1997). Integrating Scientific Expertise into Regulatory DecisionMaking. Baden-Baden: Nomos.

Kassim, H., Peterson, J., Bauer, M. W., Connolly, S., Dehousse, R., Hooghe, L., \& Thompson, A. (2013). The European Commission of the Twenty-First Century. Oxford: Oxford University Press.

Kennedy, B. (2013). Sorting through: The role of representation in bureaucracy. Journal of Public Administration Research and Theory, 23(4), 791-816.

Kennedy, B. (2014). Unravelling representative democracy: A systematic analysis of the literature. Administration and Society, 46(4), 395-421.

Kingsley, J. D. (2003). Representative Bureaucracy. In J. Dolan \& D. H. Rosenbaum (Eds.), Representative Bureaucracy: Classic readings and Continuing Controversies. New York: M. E. Sharpe.

Lægreid, P., \& Olsen, J. P. (1978). Byråkrati og Beslutninger. Bergen: Universitetsforlaget.

Lim, H. (2006). Representative bureaucracy: Rethinking substantive effects and active representation. Public Administration Review, 66, 193-205.

Maasen, P., \& Olsen, J. P. (Eds.) (2007). University Dynamics and European Integration. Dordrecht: Springer.

Meier, K. J. (1993). Latinos and representative bureaucracy: Testing the Thompson and Henderson hypotheses. Journal of Public Administration Research and Theory, 3(4), 393-414.

Meier, K. J., \& Capers, K. J. (2013). Representative Bureaucracy: Four Questions. In B. G. Peters \& J. Pierre (Eds.). The Sage Handbook of Public Administration. London: SAGE.

Meier, K. J., \& Nicholson-Crotty, J. (2006). Gender, representative bureaucracy and law enforcement: The case of sexual assault. Public Administration Review, 66, 850-860.

Miller, D., \& Turnbull, W. (1986). Expectancies and interpersonal processes. Annual Review of Psychology, 37, 233-256.

Mosher, F. (1968). Democracy and the Public Service. Oxford: Oxford University Press.

Murdoch, Z., \& Geys, B. (2014). Institutional dynamics in international organisations: Lessons from the recruitment procedures of the European External Action Service. Organization Studies. doi: $10.1177 / 0170840614544558$.

Murdoch, Z., \& Trondal, J. (2013). Contracted government: Unveiling the European Commission's contracted staff. West European Politics, 36(1), 1-21.

O'Connor, K. (2014). Public Administration in Contested
Societies. Houndsmills: Palgrave Macmillan.

Olsen, J. P. (2007). The Institutional Dynamics of the European University. In P. Maasen, \& J. P. Olsen (Eds.). University Dynamics and European Integration. Dordrecht: Springer.

Paradeise, C., Reale, E., Bleiklie, I., \& Ferlie, E. (Eds.) (2009). University Governance. Dordrecth: Springer.

Pennock, J. R. (1968). Political Representation: An Overview. In J. R. Pennock \& J. W. Chapman (Eds.), Representation. New York: Atherton Press.

Pentland, C. (1973). International Theory and European Integration. New York: The Free Press.

Peters, B. G., Schröter, E., \& von Maravić, P. (2013). Representative bureaucracy: Concept, Driving Forces, Strategy. In P. von Maravić, B. G. Peters \& E. Schröter (Eds.), Representative Bureaucracy in Action. Cheltenham: Edward Elgar Publishing.

Pfeffer, J. (1982). Organizations and Organization Theory. Marshfield: Pitman.

Pitkin, H. F. (1967). The Concept of Representation. Berkeley: University of California Press.

Pitts, D. W., Hicklin, A. K., Dawes, D. P., \& Melton, E. (2010). What drives the implementation of diversity management programs? Evidence from public organizations. Journal of Public Administration Research and Theory, 20(4), 867-886.

Radaelli, C. (1999).The public policy of the European Union: Whither politics of expertise? Journal of European Public Policy, 6(5), 757-774.

Ramirez, F. O. (2006). The Rationalization of Universities. In M.-L. Djelic \& K. Sahlin-Andersson (Eds.), Transnational Governance. Institutional Dynamics of Regulation. Cambridge: Cambridge University Press.

Rayner, S. (2003). Democracy in the age of assessment: Reflections on the roles of expertise and democracy in public-sector decision making. Science and Public Policy, 30(3), 163-170.

Rhodes, R. A. W., Hart, P. 't, \& Noordegraaf, M. (2007). Observing Government Elites. Houndmills: Palgrave Macmillan.

Rutgers, M. R., \& Mentzel, M. A. (1999). Scientific expertise and public policy: Resolving paradoxes? Science and Public Policy, 26(3), 146-150.

Savigny, H. (2013), The (political) idea of a university: Political science and neoliberalism in English higher education. European Political Science, 12(4), 432439.

Schröter, E., \& von Maravić, P. (2014). Improving Administrative Performance? How High Hopes of Diversity May Be Dashed in the Public Sector. In G. Peters, E. Schröter, \& P. von Maravić (Eds.), The Politics of Representative Bureaucracy. Power, legitimacy, Performance. Cheltenham: Edward Elgar Publishing.

Selden, S. C. (1997). The Promise of Representative Bureaucracy: Diversity and Responsiveness in Govern- 
ment Agency. New York: M. E. Sharpe.

Selden, S. C., \& Selden, F. (2001). Rethinking diversity in public organizations in the 21st century. Administration and Society, 33(3), 303-329.

Smeby, J.-C. (2000). Disciplinary differences in graduate education in Norway. Studies in Higher Education, 25(1), 53-67.

Sowa, J. E., \&. Selden, S. C. (2003). Administrative discretion and active representation: An expansion of the theory of representative bureaucracy. Public Administration Review, 63(6), 700-709.

Stevens, A. (2009). Representative bureaucracy: What, why and how? Evidence from the European Commission. Public Policy and Administration, 24(2), 119-139.

Stone, D. (2012) Agents of Knowledge. In D. Levi-Faur (Ed.), The Oxford Handbook of Governance. Oxford: Oxford University Press.

Sutcliffe, K. M., \& Weick, K. (2008). Information Overload Revisited. In G. P. Hodgkinson \& W. H. Starbuck (Eds.), The Oxford Handbook of Organizational Decision Making. Oxford: Oxford University Press.

Trondal, J. (2013). Organized Systems and the Ambiguities of Behavior and Change: Observations from Universities and Jazz Orchestras. In J. Holbek, S.
Kristiansen, \& T. Randøy (Eds.), Management for Progress. Oslo: Novus Press.

Trondal, J. (2014). Agencification. Public Administration Review, 74(4), 545-549.

Trondal, J., Murdoch, Z., \& Geys, B. (2014). Representative bureaucracy in international organizations. Unpublished paper.

Trondal, J., Suvarierol, S., \& van den Berg, C. (2008). The compound machinery of government. The case of seconded officials in the European Commission. Governance, 21(2), 253-274.

Watts, J. H. (2009). Leaders of men: Women "managing" in construction. Work, Employment \& Society, 23, 512-530.

Weingart, P. (1999). Scientific expertise and political accountability: Paradoxes of science in politics. Science and Public Policy, 26(3), 151-161.

Whitaker, G. P. (1980). Co-production: Citizen participation in service delivery. Public Administration Review, 40, 240-46.

Wilson, J. Q. (1989). Bureaucracy. New York: Basic Books.

Wrong, D. H. (1970). Max Weber. Englewood Cliffs: Prentice Hall.

\section{About the Authors}

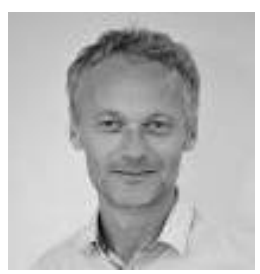

\section{Dr. Jarle Trondal}

Jarle Trondal is Professor of Political Science and Public Administration at University of Agder, Department of Political Science. He is also Professor of European Studies at University of Oslo, ARENA Centre for European Studies, and Honorary Professor at University of Copenhagen. His main research interests are in public administration, organizational studies, and the study of European political order transformation.

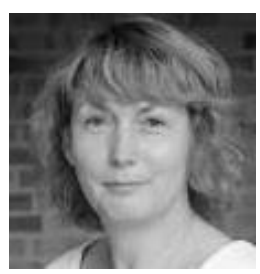

\section{Dr. Zuzana Murdoch}

Zuzana Murdoch is Senior Research Fellow at the University of Bremen and associated researcher at the University of Agder (Kristiansand, Norway). Her main research interests concern the role and influence of the administrative level in EU governance and policy-making. Some of her work has appeared in journals including Organization Studies, Journal of European Public Policy, Journal of Common Market Studies, West European Politics and Public Administration.

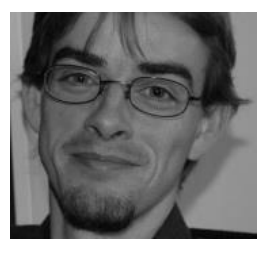

\section{Dr. Benny Geys}

Benny Geys is Research Professor at Vrije Universiteit Brussel (VUB) in Brussels and Associate Professor in Economics at the Norwegian Business School (BI) in Oslo. His research predominantly focuses on intergovernmental relations, civic engagement and political accountability. Some of his work has appeared in journals including Economic Journal, Journal of the European Economic Association, Organization Studies, Public Opinion Quarterly and European Journal of Political Research. 